\title{
ANL/DIS/PP- 84035
}

A HISTORICAL APPLICATION OF SOCIAL AMPLIFICATION OF RISK MODEL: ECONOMIC IMPACTS OF RISK EVENTS AT NUCLEAR WEAPONS FACILITIES? *

\author{
by
}

\author{
William C. Metz, Ph.D**
}

\section{INTRODUCTION}

Public perceptions of risk have proven to be a critical barrier to the federal government's extensive; decade-long, technical and scientific effort to site facilities for the interim storage and permanent disposal of high-level radioactive waste (HLW). The negative imagery, fear, and anxiety that are linked to "nuclear" and "radioactive" technologies, activities, and facilities by the public originate from the personal realities and experiences of individuals and the information they receive. These perceptions continue to be a perplexing problem for those responsible for making decisions about federal nuclear waste management policies and programs. The problem of understanding and addressing public perceptions is made even more difficult because there are decidedly different opinions about HLW held by the public and nuclear industry and radiation health experts, (1) a sample of radiation health scientists overwhelmingly believe the public's fear of radiation is substantially greater than realistic (Cohen, 1986), and (2) there are scientists and engineers who view nuclear technologies in a more positive manner and feel that interim storage and geologic disposal can be made safe (Flynn et al., 1993). In addition, there are apparent paradoxes between what people provide as responses to image and location preference

*Work supported by the U.S. Department of Energy, Office of Civilian Radioactive Waste Management, under Contract W-31-109-ENG-38. The Material presented in this paper is the opinion of the author and in no way reflects the policies or position of this federal agency.

**Program Manager/Coordinator, Decision and Information Sciences Division, Argonne National Laboratory, Argonne, IL 60439 


\section{DISCLAIMER}

This report was prepared as an account of work sponsored by an agency of the United States Government. Neither the United States Government nor any agency thereof, nor any of their employee, make any warranty, express or implied, or assumes any legal liability or responsibility for the accuracy, completeness, or usefulness of any information, apparatus, product, or process disclosed, or represents that its use would not infringe privately owned rights. Reference herein to any specific commercial product, process, or service by trade name, trademark, manufacturer, or otherwise does not necessarily constitute or imply its endorsement, recommendation, or favoring by the United States Government or any agency thereof. The views and opinions of authors expressed herein do not necessarily state or reflect those of the United States Government or any agency thereof. 


\section{DISCLAMMER}

Portions of this document may be illegible in electronic image products. Images are produced from the best available original document. 
observed behavior does not support predicted negative effects based on those responses (Metz, 1994). Nevertheless, the public's perceptions of risk and fears cannot be ignored or subverted during siting activities awaiting the development of indisputable engineering, technological, or scientific evidence.

Federal policymakers feel it is critical to resolve issues related to the interim storage and permanent disposal of the growing volume of spent nuclear fuel (SNF) produced by this nation's 112 civilian nuclear reactors and the HLW created as a by-product during nuclear weapons production. The U.S. Congress expedited the repository siting process by amending the Nuclear Waste Policy Act in 1987, designating the Yucca Mountain site in Nevada as the sole candidate for a $\$ 6$ billion characterization effort to determine its suitability as a permanent disposal site. In parallel, a volunteer siting process was created for a Monitored Retrievable Storage (MRS) facility and repository. Each new siting attempt by the U.S. Department of Energy (DOE) or the independent Office of the United States Nuclear Waste Negotiator has met strong and vocal resistance based on the public's perceptions of risk. State government officials and many researchers ardently claim that being a host to such a facility could possibly result in a potential stigmatization and substantial economic losses (Slovic et. al., 1991). When several Native American tribes expressed strong interest in hosting a MRS, affected state congressional delegations prevailed in stopping the siting activity by having Congress eliminate critical grant funding. This siting issue appears to be one of the nation's most difficult, contentious public policy challenges.

The state of Nevada has taken a strong public policy position that opposes the Congressionally-forced site characterization of Yucca Mountain in response to a majority opinion of the state's residents. In a 1994 State-sponsored survey, 69\% were opposed. Nevada's concern about perceived risk and stigma impacts was the primary basis (economic 
endangerment) for an unsuccessful lawsuit against DOE filed by the Nevada Attorney General in the United States Ninth Circuit Court of Appeals. The State had declared a veto action and served a notice of disapproval regarding the selection of the Yucca Mountain site for development of a HLW repository.

An extensive research program supports Nevada's claim that hosting a repository could lead to possible-stigmatization and potential significant losses to the economic sectors at risk, especially the imáge-sensitive city of Las Vegas. The claim is based on two premises. First, the intense, negative imagery associated with nuclear wastes that was elicited in over two dozen surveys of Nevada, Arizona, and California residents, of national populations, and of organizations (Mountain West Research, 1989; Flynn et al., 1990; Mushkatel et al., 1990; Easterling, Kunreuther, 1993). Second, a conceptual framework for a social amplification of risk model which postulates that repository-related stimuli or key risk events can be transformed (via various complex information and social processes and pathways) into massive indirect social and economic impacts (Kasperson et al., 1988; Burns et al., 1993; Renn, 1993). The purpose of this article is to determine if the aforementioned social amplification of risk model, developed to explain the potential social and economic impacts from a possible repository facility, can be historically applied to analogous DOE Nuclear Weapons Complex facilities. These facilities have strong similarities: managed by DOE, hold radioactive wastes, and are associated with comparable minor and major discrete and cumulative risk events. It is imperative to determine whether aspects of the model of social amplification of risk are uniquely related to a repository or whether the model's predictive capability can be measured by behavior patterns and secondary and tertiary economic and social impacts at a variety of other DOE nuclear-related facilities, both existing and planned? APPLICABILITY OF THE SOCIAL AMPLIFICATION OF RISK MODEL 
The conceptual framework for the social amplification of risk model attempts to link systematically the technical assessment of risk with psychological, social, cultural, and institutional processes that can amplify or attenuate public perceptions of risk and related risk behavior and consequences. Kasperson et al. (1988) used the term "social amplification of risk" to refer to the mechanisms by which the occurrence of an adverse event can extend far beyond its direct damage, triggering rippling behavior that introduces substantial temporal and geographically extended secondary social and economic consequences. Social amplification of risk supports Nevada's claim that a host area for a HLW facility would be vulnerable to minor and major negative risk events related to "nuclear" and "radioactive" images. Slovic et al. (1991) stated that because of "our society's strong response to mishaps involving nuclear power and nuclear wastes," news of each nuclear mishap around the world is immediately presented in the media and quickly elevated to the public's attention.

Weapons Complex facilities, which have many of the same characteristics as a repository or interim storage facility, should offer a viable, empirical research opportunity for testing the model's theoretical assumptions. The historical application relied on facilityrelated information presented in local, state, and national news media, which are the primary amplifiers of risk events, and on existing survey data. Two major model components were investigated in this initial application:

- Key risk events. Minor and major discrete and cumulative key risk events mentioned in HLW-related surveys were compared with those identified as occurring at DOE Weapons Complex facilities.

- Social and economic consequences. A preliminary review of the social and economic conditions around Weapons Complex facilities was performed to assess possible consequences that could be related to key risk events. 
Performing a historical application of the social amplification of risk model is a valuable step toward seeking to better understand and address public perceptions of risk. Kasperson et al. (1988) state that their model conceptualization needs "scrutiny, elaboration, and competing views." In a discussion of the limitations to the social amplification of risk model, Burns et al. (1993) note that "more research is needed to determine how well intentions predict public_response to risk. Similarly, the behavioral intentions university students display toward a hazardous event may be different than those of the general population." Until greater primary research is initiated, secondary media information and survey data, often incomplete and reflecting various interpretations and biases, can be used for an initial assessment of the social amplification of key events and resulting behavioral responses. It is critical to begin to stimulate a dialogue on whether the conceptual framework is repository specific or can be applied to all DOE nuclear-related facilities.

\section{KEY RISK EVENTS}

The purpose of the conceptual framework was "to begin the building a comprehensive theory that explains why seemingly minor risks or risk events often produce extraordinary public concern and social and economic impacts, with rippling effects across time, space, and social institutions" (Kasperson et al. 1988). Survey data reveal that the public believes there is a likely potential for HLW facility and transportation accidents, with accompanying negative economic, health, and environmental consequences. According to the U.S. Congress, Office of Technology Assessment (1991), almost all Weapon Complex facilities "have experienced strongly articulated public concern and adversarial activity" as a result of activities and events that have occurred, thereby increasing both a site-specific and complexwide media exposure. What is at issue is whether the myriad of key risk events occurring 
at Weapons Complex facilities have the same high signal strength and amplified triggering effects as those mentioned in surveys that could accompany a repository situated in Nevada or a MRS located elsewhere.

\section{Key Risk Events Mentioned in Surveys}

People's perception thiat there is a potential for key risk events to originate from the interim storage, disposal, or transport of nuclear materials has been the subject of numerous surveys. Local, state, regional, and national populations, as well as various organizations, have been asked for their opinions about different accident and contamination scenarios, ranging in magnitude from no radioactive releases and contamination to major releases and contamination and from minor injuries to multiple deaths. The purpose has been to statistically determine the extent of the public's belief in the probability of various types of risk events and its perception of the severity and duration of the consequences of these events. Questions alluding to factors that could elevate or dampen a person's perception of risk have also been asked, such as those related to the degree of trust the person has in those who could be involved in the potential risk event, the person's knowledge of HLW, facility management competency, and whether there is open sharing of scientific and accident data.

Surveys related to a repository have focused on residents of Washington, Texas, and Nevada - past and present candidate states for repositories. They show the strength of perceived impacts. Desvouges et al. (1993) found that approximately $75 \%$ of both a national and Nevada sample either agreed or strongly agreed that an accident at a repository would involve certain death, over $80 \%$ in each thought an accident would be catastrophic, $63 \%$ perceived that large accidental releases of radiation from a repository were somewhat or very likely, and approximately $75 \%$ believed repository wastes would leak radiation into 
groundwater. Brady and Fleishman (1993) found a large majority of Texas Panhandle residents agreed that the expected environmental risks of a repository were radiation in the water, food contamination, health problems for workers, radiation in the air, and health problems for residents. Dunlap et al. (1993) found forty percent of the respondents in the Washington state Tri-Cities area felt that a HLW repository at the Hanford Nuclear Reservation could somewhat or very likely lead to radioactive contamination of the Columbia River, $51 \%$ expected that people might hesitate about buying agricultural products grown in or near the area.

Almost a dozen surveys have asked questions related to accidents involving the transport of nuclear wastes to a repository. A majority of respondents believe there will be transportation accidents. Slovic et al. (1993) found the percentages of respondents who agreed or strongly agreed that highway and rail accidents would occur were $77 \%$ in Nevada, $69 \%$ in California, and $72 \%$ nationally. Dunlap et al. (1993) in a survey of Hanford Nuclear Reservation area residents, found 50\% expected that dangerous accidents would occur; Brady and Fleishman (1993) found $80 \%$ had a similar belief in a Texas survey.

In a survey of convention planners, Easterling and Kunreuther (1993) elicited opinions on the potential for a negative effect from a repository by presenting a range of facility operating scenarios. They were asked if they would still choose Las Vegas as a convention site when confronted with each of seven scenarios, ranging in severity from benign operations (no accidents over the first 10 years of repository operation), to more serious scenarios (e.g., minor and moderate repository and transportation accidents involving cases of radiation exposure), to even more serious scenarios (e.g., multiple mishaps leading to 15 cases of radiation exposure and a higher-than-expected risk condition being present). Those who are predicted to change from a Las Vegas meeting location ranged from between 
$12 \%$ and $36 \%$ of the sample under a benign scenario to between $47 \%$ and $80 \%$ under the most severe scenario of multiple mishaps with amplified media attention.

Surveys related to the possible siting of interim storage facilities in Tennessee conducted by Fox et al. (1985) show respondents are concerned about its harmful characteristics. Jenkins-Smith (1993) elicited similar concerns from New Mexico and Idaho residents about the likelihood of accidental releases from the temporary storage, transport, and permanent storage of transuranic wastes and the consequences of those releases, including death and serious illness, uninhabitability of land in the vicinity of the accidents, and possible remediability of the area over time.

Surveys have consistently shown that the public strongly believes that accidents with significant consequences will accompany the storage, disposal, and transport of HLW. Kasperson et al. (1988) predict the accompanying adverse social and economic impacts, because events surrounding nuclear power generally have a high signal value (i.e., even relatively minor incidents eliciting strong public reaction). Issues of trust, scientific integrity, and management competency, although they are not key risk events, have been shown to be significant factors in elevating or dampening the reaction to risk events. Because DOE and the repository program have received low evaluations in several surveys on trust and management capabilities, the perception of risk associated with the DOE program is presumably amplified and asymmetrical. 


\section{Key Risk Events at Weapons Complex Facilities}

The Weapons Complex consists of 15 major facilities in 12 states employing nearly 100,000 people and covering approximately 3,500 square miles. For more than 40 years, these facilities have been producing uranium materials and irradiating them in nuclear reactors, reprocessing these materials to separate weapons constituents, manufacturing and finishing weapons cơmponents, producing special parts, assembling and testing weapons, conducting research and designing new weapons, and recycling parts when weapons are retired.

DOE and its Weapons Complex facilities have been recipients of an increasing amount of negative and highly emotional attention from local, regional, and national print and televised media related to past and present on-site and off-site disasters, contamination, mismanagement, spills, releases, exposures, accidents, and deaths, as well as heightened concerns about impending chemical explosions. The Fernald Plant (Ohio), Rocky Flats Plant (Colorado), Savannah River Site (South Carolina), Oak Ridge Reservation (Tennessee), Hanford Nuclear Reservation (Washington), Pantex Plant (Texas), Idaho National Engineering Laboratory (Idaho), and Nevada Test Site (Nevada) are the most recognized DOE nuclear weapons facilities. Since 1990, at least eight class-action lawsuits that have been filed against DOE or its contractors are related to possible property value losses and health impacts at weapons plants in Colorado, New Mexico, Ohio, Tennessee, and Washington. A congressional report by the U.S. Congress, Office of Technology Assessment (1991), places the blame on an overemphasis on production for national security, outdated equipment and facilities, manufacturing processes that were inherently waste producing, lack of attention to environmental contamination, inadequate safety and health oversight, insufficient funding, and existing environmental and hazardous waste problems. Additional 
revelations about facility environmental, safety, and health problems and off-site inferences will probably become more common under the aggressive leadership of DOE Secretary O'Leary, who advocates open and participatory public and stakeholder involvement in facility decision-making and planning.

The public has been presented with a extensive litany of key discrete and cumulative minor and major riskevents involving Weapons Complex facilities. Accounts are of:

- Previously secret plutonium storage locations;

- Potentially explosive leaking underground HLW storage tanks;

- Significant deterioration of federal SNF kept in defective storage pools;

- Tritium spills and leaks into major rivers and aquifers;

- Large numbers of workers exposed to unacceptable levels of radioactivity;

- Worker deaths from accidents;

- Uranium contamination in off-site wells and aquifers;

- Hundreds of intentional and unintentional radioactive releases, several hundreds of thousands of times more potent than that of the Three Mile Island accident;

- Safety board concerns about procedures for dismantling nuclear weapons;

- Transportation accidents and incidents involving nuclear materials; and

- Revelations of possible and actual off-site health problems.

Past and present key risk events at these facilities could conceivably be considered worse than those expected to accompany a new HLW repository or interim storage facility. Reason being the evolving, strident change in the management culture within DOE away from secrecy and a fixation on weapons production, no matter the cost, to one of greater regulatory compliance and citizen involvement. This will be accompanied by an internal 
implementation of higher standards for environment, safety, and health, including management and contractor accountability.

\section{ECONOMIC CONSEQUENCES OCCURRING NEAR WEAPONS COMPLEX}

\section{FACILITIES}

The social plification of risk model predicts that key risk events, especially nuclear and radioactive incidents, can cause substantial social and economic consequences. Therefore, in host areas surrounding Weapons Complex facilities, effects should be apparent. The current social and economic conditions around Weapons Complex facilities reflect a history of more than 40 years, during which a multitude of discrete and cumulative key risk events interacted with dynamic site-specific and area-specific social and economic variables (e.g., site mission, employment characteristics, diversity and stability of regional economic sectors, demographic profiles, area amenities and disamenities, trust relationships, and community interactions with site management).

A preliminary assessment of effects was made by using information from the media, personal observations, and reports. There was an apparent lack of readily observable effects, contrary to the model's assertions. This could be the result of (1) local familiarity with risk and nuclear technology, (2) the fact that most of the more profound risk event stories have come to light only within the past decade, (3) the overriding attraction of employment opportunities directly or indirectly offered by the facilities, (4) personal denial of harm among the population, or (5) a subtle shift within the population to acquiescence. A more extensive empirical scrutiny of site host areas to find social and economic effects that could stem from key risk events to corroborate the model or explain this lack of evidence is necessary. Two 
significant economic indicators used as a preliminary measure of the effect of key risk events on host areas of Weapons Complex facilities are: property values and business activity.

\section{Property Values}

Property values reveal the equilibrium relationship between supply and demand on the basis of what a purchaser decides the value of the property to be. They can also reveal an increase in demand generated by a commensurate increase in Weapons Complex and area employment, and they can show the level of acceptance or acquiescence by area residents and those in-migrating to the area. Real estate markets, as do many markets in our society, dynamically reflect the beliefs, attitudes, and reactions of buyers and sellers. Buyers and sellers respond to market facts and information on the basis of those beliefs and attitudes, regardless of whether they are factually correct.

Evaluating how a facility or transportation activity related to radioactive waste affects property values in the host areas is possible by several means. These can include market analyses, housing statistics, and court proceedings.

A market analysis uses a history of tax assessment records, sale prices, and comparable properties are compared with similar properties that are distant and unaffected by the facility's influence. This was the case when the Fernald Plant was the subject of a 1986 lawsuit that claimed a diminution of property values within a 5-mile radius after residents learned of a release of between 200,000 and 3 million pounds of uranium into the environment. As part of a $\$ 78$ million settlement, property owners in the vicinity of the Fernald Plant are to be compensated for any diminution of value or less than normal appreciation between 1984 and 1990. During that time, the facility came under intense scrutiny for a number of key risk events, including mismanagement, worker carelessness, 
exposure of workers, hazardous waste contamination of the underground aquifer, presence of uranium in off-site wells, and noncompliance with state safety and environmental regulations. Media accounts (Neus, 1992; Feiertag, 1992) report that a subsequent loss of property value was found to exist for a radius of approximately 1.5 miles from the plant and for 3 parcels adjacent to a contaminated creek 3 miles away. Adjacent agricultural land values declined as much as 53\%; dairy farming and agricultural production continue on the land. Residence values within 1 mile decreased 10-21\%; construction of new homes continues within that ring. Similar diminution-of-property value lawsuits are in progress by neighbors of the Rocky Flats Plant and the Portsmouth Gaseous Diffusion Plant.

By relying on various housing data (e.g., median sale prices, electrical connections, building permits, and occupancy data), the media has been reporting an increased demand for housing and that housing values have been rising near Weapons Complex facilities. For example, in the Tri-Cities area that supports the Hanford Nuclear Reservation, it is reported that homes cannot be built fast enough (Long, 1993). The median price for previously owned single-family homes in Richland, Washington, jumped $21 \%$ in 1993, the biggest increase of any U.S. city (Memmott, 1993). Even with highly publicized site characterization activities continuing at Yucca Mountain, Thurlow of the Pahrump Times (1993) reported the nearby Nye County communities of Beatty, Pahrump, and Amargossa Valley continued to explode, and Pahrump gained 200 new residents in a 45-day period. The City of Oak Ridge has successfully acquired 704 acres from the Oak Ridge Reservation (ORR) for continued residential, industrial, and service sector development.

Court proceedings have determined risk-related market effects. To determine losses in property values due to fear or perceptions of risk within the United States, three judicial approaches exist in state and federal circuit courts. Most involve overhead high-voltage lines. 
- The first view is that fears of prospective purchasers are generally compensatible without having to prove the fears are reasonable, but evidence must support the conclusion that property value has diminished. This approach has been adopted in federal cases in two circuit courts and eight state courts.

- The second view is that fears must be shown to be reasonable, to be grounded in scientific observations or experience, and to affect market value. This approach has been adopted in nine state courts.

- The third view is that speculative fear is not a reason for granting compensation for the alleged diminished value of property. This approach has been adopted in four state courts.

In a condemnation action related to the transport of transuranic waste to the Waste Isolation Pilot Project (WIPP) site, the Supreme Court of the State of New Mexico (City of Sante Fe vs. Komis, 1992) adopted the first view. The court determined market value in ruling that compensation be awarded for loss of market value, even if the loss is based on fears not founded on objective standards. Expert testimony of a real estate appraiser and a public opinion poll were sufficient to prove there would be a loss in value because of the public's perception that people would purchase the remaining land only at a reduced price because of the fear of living or working near a nuclear waste transportation route. In this case, no comparable sales data were provided, and the reasonableness of the fear was not an issue. The case is applicable only to cases involving partial condemnations and only in states or federal courts where the first judicial approach is accepted. Nevada's Supreme Court has not yet been confronted with the issues of public perceptions of risk and reasonableness of fear related to property values, so the judicial approach it will follow is unknown. 


\section{Business Activities}

Business activities have steadily expanded outward from population centers and now encroach on the previously remote, secret Weapons facilities. Different types of businesses have varying reasons for selecting sites in proximity and making operational decisions. Agricultural activities are location dependent and directly respond to consumer demands and concerns. Manufacturing and service sector siting decisions are significantly influenced by a firm's size, product structure, functional organization, occupational characteristics, mode of transportation, and personal preferences of management. In a survey of firms, Allison (1993) found that when a firm has locational flexibility, amenity factors, such as the natural and cultural environment, become more important in siting decisions. Initial research by Allison et al. (1993) found no significant negative economic effects of commercial and federal nuclear facilities on the hosting local communities; the greater the quality of the nuclear facility's participation with a host community, the better the acceptance.

State and local government officials, supported by area economic development agencies, have aggressively sought to extend the lifespan, as well as expand the operation of their existing Weapons Complex facilities, not close them. Ohio business and political communities attempted to retain tritium-related work at the Mound site and uranium enrichment activities at Piketon. Eighty-five percent of Amarillo-area residents surveyed "indicated that they were favorable or leaned favorably toward expanding the Pantex Plant (Timms, 1991). There has been strong state pressure to continue the testing of nuclear weapons at the Nevada Test Site (NTS).

The financial community has examined the economic future of adjacent and host cities and counties, upgrading bond ratings. Two locations are the City of Las Vegas (even at the time of the passage of the 1987 Nuclear Waste Policy Act Amendment designating 
Yucca Mountain for characterization and continued nuclear testing)(Metz, 1992) and Aiken County, South Carolina, host to SRS, which received the highest rating available (Steele, 1994).

Tourism and recreational activities continue to grow in the vicinity of Weapons Complex facilities. New mega-resorts are being constructed in Las Vegas, 65 miles from the NTS, and more are planned as the City seeks to promote a revised image as a family resort. Facilities are in proximity to flourishing vacation areas (Hilton Head, Tampa, Colorado Rockies and Great Smoky Mountains) and annual national tournament events (Masters at Augusta National). Facilities have expanded their visitor centers, offer site tours, and provide special use permits for conference centers (University of Georgia is to construct the Savannah River Ecology Laboratory Conference Center at SRS). On-site recreational areas exist for nonexclusive use by area communities and organizations. Controlled hunting for large game animals is allowed on ORR, SRS, and INEL properties.

Weapons Complex facilities have taken on a new responsibility related to supporting economic diversity both on site and within area communities. Site land, buildings, infrastructure, and research facilities are sought for alternative development, optimizing their reuse by university, private industry, and entrepreneurs and bolstering local economies. The City of Miamisburg, Ohio, is actively working with DOE to commercialize the Mound site and make use of the facility's resources; requesting a portion for an industrial park. Plans are for the Pinellas facility in Largo, Florida, to be an incubator center for developing new businesses. DOE and a consortium of local agencies at Hanford have joined to open the Agribusiness Commercialization and Development Center to assist in moving agriculturalrelated technology from the laboratory to the private sector. Industrial parks are being developed by the private sector on land adjacent to the SRS facility and on land secured from 
the ORR facility. A medical center is expanding onto former ORR facility property. The former Clinch River Breeder Reactor Project site, adjacent to ORR, was a finalist in the Mercedes-Benz siting derby.

Although, regional business activities have been disrupted because of regulatory agency actions following a facility risk event, no lasting economic effects have been evident or reported. This was the case when the restart of a SRS reactor in December 1991 resulted in a very publicized second spill of tritium into the Savannah River (Applebome, 1992). This event led to a State-enforced, several-day closure of river-using industries and water companies. DOE disputed the closure and the State's interpretation of health standards. Despite this, four downriver companies were compensated for their documented costs to acquire alternate sources of water, provide overtime pay to make engineering adjustments, and purchase equipment during the closure period. Since 1989, the media (The State 5/26/92) has reported that relocating companies and on-going business expansions have created 1,200 new jobs in the SRS host county - Barnwell County, South Carolina. At Hilton Head, South Carolina (100 miles southeast), Del Webb Corporation recently announced the development of a new 5,300-acre adult community. Meanwhile, County officials recently offered to host an interim storage facility for SNF from the State's commercial reactors.

There is a public perception that consumers might develop a belief that host area agricultural products are contaminated. The Dallas Morning News (11/13/93) reported that farmers worry that "Pantex's growing plutonium reputation will chase produce buyers from the High Plains, where agriculture provides a $\$ 3$ billion industry annually." However, agriculture continues to be practiced on and in the vicinity of several Weapons Complex facilities with no evidence of economic harm. Dairy herds graze on leased site property and in close proximity to the Fernald facility, and the milk (rigorously tested) is sold to area 
markets. Private livestock graze on designated portions of the INEL site, property leased from the State of Colorado adjoining the Rocky Flats facility and on property owned and leased by Texas Tech University at the Pantex facility. Agricultural enterprises involving orchards, vineyards, forage crops, and farm produce also exist in close proximity to most facilities. Agricultural interests presently covet several Complex properties; for example, area farmers and local politicians are countering a proposal to designate the northern part of the Hanford Nuclear Reservation, formerly a buffer area, as a wildlife refuge, proposing instead it be divided into both farmland and a nature preserve.

A "halo effect" of positive attitudes by residents appears to surround Weapons Complex facilities and the technologies present. The effect can be attributed to several factors, such as people's familiarity with the facility over time, the fact that they volunteered to locate there, their heightened safety training, and the fact that they have more information engendered through their or their neighbors' employment at the facility. Jenkins-Smith (1993) found those living near the INEL facility, versus their counterparts residing elsewhere in Idaho, feel that there is less likelihood of an accidental release from transuranic waste storage or transport and that any accidental contamination could be cleaned up quickly. Lackland et al. (1993) found proximity is also an issue at SRS where approximately $40 \%$ of those residing within 50 miles had a good attitude toward the facility, while less than $25 \%$ of those residing within $50-100$ miles and about $12 \%$ of those residing more than 100 miles had good attitudes. The media (Willette, 1990; Sharp, 1990)) have often stated, "knowledge, faith keep DOE neighbors at ease" and "residents comfortable with legacy." These reasons may explain why no significant social and economic effects are apparent in areas surrounding Weapon Complex facilities. This local faith, accompanied by strong caveats for local oversight, financial guarantees, impact mitigation, economic diversity, 
environmental compliance, rigorous monitoring, emergency preparedness, and science education, caused the Clinch River MRS Task Force (1985), composed of local governments, to accept the siting of the MRS facility at the Clinch River site, a decision overturned by the State of Tennessee.

Distance is also a factor in Nevada regarding risk concerns over the NTS and support for siting the repository at Yucca Mountain. Krannich et al. (1993) found that residents of the rural Nevada communities of Amargosa Valley, Beatty, Indian Springs, and Pahrump, all in the vicinity of NTS, have low average concerns about the consequences of activities at NTS. Similarly, perceptions of risk concerning the repository are weakest in the four rural communities nearby and strongest in urban communities farthest away from the site. This decreased concern and actual support for a repository by rural communities nearby is the result of a complex set of factors, ranging from the unique sociocultural settings, divergent NTS experiences and perceptions, a positive risk perception shadow of being upwind of NTS, and cross-generational concerns when addressing long-term hazards. There is also an anticipation of further positive economic opportunity, not to be equated with economic desperation. At this point, predictions of potential adverse economic effects have not been confirmed, development officials from Nevada have stated in the media (Tetreault, 1991) that the "prospect of Nevada someday becoming the home of a nuclear waste repository has not been an issue among companies considering whether to locate in the state..." Local support for repository site characterization activities at Yucca Mountain has been overridden by the State of Nevada, as have all state governors overridden any desires by local communities to host an MRS. 


\section{CONCLUSIONS}

It is imperative that the public's perceptions of risk associated with facilities for the interim storage and permanent disposal of HLW be addressed by Federal policymakers. The Nuclear Waste Technical Review Board, in a February 24, 1994, letter report to Congress, recognized this very emotional public concern and recommended that "public perceptions about the potential risks associated with nuclear power and the waste it generates must be addressed." Ardent claims of the potential for significant economic impacts at host locations have accompanied and become a critical barrier to DOE's continuing scientific and technical effort to site these facilities.

Extensive research into public perceptions of risk surrounding a possible HLW repository has focused on two points - imagery and social amplification of risk. Survey results show that the public possesses negative imagery and a deep sense of foreboding in association with nuclear and radioactive technologies and storage and disposal facilities. A conceptual framework for the social amplification of risk model was developed to explain the complex mechanisms by which discrete and cumulative risk events affect people's behavior. By virtue of the surveys and model, siting opponents have stated that public perceptions of risk and the accompanying fear can only be addressed by halting all siting activities for interim storage and permanent disposal facilities. They propose maintaining the SNF in place at reactors, though they have performed no comparable risk perception analysis.

At issue is whether the amplification of risk model accurately illustrates the actual mechanisms by which nuclear risk-related events and negative imagery are predicted to cause substantial social and economic consequences to a state hosting a repository or a MRS facility or to a transport corridor for such facilities? If the model could be applied universally, the communities that host Weapon Complex facilities should prove to be suitable 
for a historical application of the model. The Weapons Complex facilities have strong similarities to the HLW facilities currently being sited because they are managed by DOE, have radioactive waste present, and have been subject to high-profile discrete and cumulative risk-related events. Most events at Weapons Complex facilities have been greatly amplified in the media and cross-referenced with an extensive litany of risk events involving nuclear technology at other nuclear facilities. It can then be assumed that substantial social and economic consequences should be observable in areas hosting Weapons Complex facilities from that universe of events. These consequences are not readily apparent. The model needs to take account of the differing circumstances under which risk events were perceived and acted on by host areas and their residents as well as the factors that have generally served to attenuate behavior from discrete and cumulative risk events. Empirical observation and assessment are critical to validating a model and modifying it to better reflect reality.

The answer to understanding and addressing public perceptions of risk may reside in placing the survey responses and model claims in context by focusing on the dynamics of perceptions and behavior. Perceptions must be assessed in the context of this nation's nuclear "omnipresence" (several hundred nuclear facilities and continual movement of nuclear materials along its rail and highway networks). In addition, the public does have some very positive feelings toward nuclear technologies used in the medical field and for energy production. To have researchers extrapolating policy recommendations from frequency distributions of survey responses and images and a partially tested conceptual model - without fully researching and explaining (1) what the complex causes of these perceptions are, (2) how the perceptions are acted upon, (3) why paradoxes exist between claims and reality, (4) how people acquiesce or accept the risk, (5) how risks can be managed in a participatory manner, (6) whether the public understands the policy issues in context 
with alternative storage and disposal solutions, and (7) what the public prefers as alternative solutions - diminishes public involvement in the HLW decision-making process. The research community must be able to identify and validate behavior linkages between nuclear and radioactive key risk events and significant social and economic consequences prior to proposing national policy changes. 


\section{REFERENCES}

Allison, T. 1993. Socioeconomic Assessment Guidance Report: Determining the Effects of Amenity Characteristics on Business Locations. ANL/EAIS/TM-85. Argonne, IL: Argonne National Laboratory.

Allison, T. et al. 1993. An Analysis of the Formation, Expression and Economic Impact of Risk Perceptions Surrounding Nuclear Facilities. ANL/EAIS/TM-88. Argonne, IL: Argonne National Laboratory.

Applebome, P. 1992. "Anger Lingers After Leak at Atomic Site." The New York Times 13 January.

Brady, J.G. and J. K. Fleishman. 1993. "Sources of Public Concern About Nuclear Waste Disposal in Texas Agricultural Communities." In Public Reactions to Nuclear Waste: Citizen's Views of Repository Siting, edited by R.E. Dunlap et al., 115-135. Durham, NC: Duke University Press.

Burns, W.J. et al. 1993. "Incorporating Structural Models into Research on the Social Amplification of Risk: Implications for Theory Construction and Decision Making." Risk Analysis 13: 611-624.

Clinch River MRS Task Force. 1985. Report of the Clinch River Task Force. Oak Ridge, TN.

Cohen, B.L. 1986. "A Poll of Radiation Health Scientists." Health Physics 50: 639-644.

Desvouges, W.H. et al. 1993. "Perceived Risk and Attitudes Toward Nuclear Wastes: National and Nevada Perspectives." In Public Reactions to Nuclear Waste: Citizen's Views of Repository Siting, edited by R.E. Dunlap et al., 175-208. Durham, NC: Duke University Press.

Dunlap et al. 1993. "Local Attitudes Toward Siting a High-Level Nuclear Waste Repository at Hanford,Washington." In Public Reactions to Nuclear Waste, edited by R.E. Dunlap et al., 135-174. Durham, NC; Duke University Press.

Easterling, D. and H. Kunreuther. 1993. "The Vulnerability of the Convention Industry to the Siting of a High-Level Nuclear Waste Repository." In Public Reactions to Nuclear Waste, edited by R.E. Dunlap et al., 209-238. Durham, NC: Duke University Press.

Feiertag, J. 1992. "Fernald Not Too Neighborly For Home Values." Journal-News 27 March.

Flynn, J. et al. 1990. Evaluations of Yucca Mountain Survey Findings about Attitudes, Opinions, and Evaluations of Nuclear Waste Disposal and Yucca Mountain, Nevada. NWPOSE-029-90. Carson City, NV: State of Nevada Agency for Nuclear Projects/Nuclear Waste Project Office.

Flynn, J. et al. 1993. "Decidedly Different: Expert and Public Views of Risks from a Radioactive Waste Repository. "Risk Analysis 13: 643-648. 
Fox, W.F. et al. 1985. An Economic Analysis of a Monitored Retrievable Storage Site for Tennessee, Knoxville, TN: Center for Business and Economic Research.

Jenkins-Smith, H. 1993. Public Assessments of the Risks from Managing Transurancic Wastes: The View From Idaho and New Mexico. Albuquerque, NM: University of New Mexico Institute For Public Policy.

Kasperson, R.E. et al. 1988. "The Social Amplification of Risk: A Conceptual Framework." Risk Analysis 8: 177-187.

Krannich, R.S. et at. 1993. "Rural Residents' Views of Nuclear Waste Repository Siting in Nevada." In Public Reactions to Nuclear Waste: Citizens Views of Repository Siting, edited R.E. Dunlap et al., 263-287. Durham, NC: Duke University Press.

Lackland, D.T. et al. 1993. "Perceived Risk in Geographic Areas in Proximity to a Nuclear Production Facility." Savannah, GA: Society of Risk Analysis Annual Meeting.

Long, J. 1993. "Hanford Cleanup Creates Boom." The Oregonian 18 September.

Memmott, M. 1993. USA Today 27 December.

Metz, W.C. 1992. "Perceived Risk and Nuclear Waste in Nevada: A Mixture Leading to Economic Doom?" Impact Assessment Bulletin 10: 23-42.

Metz, W. 1994. "Potential Negative Impacts of Nuclear Activities on Local Economies: Rethinking the Issue." Risk Analysis 14.

Mountain West Research. 1989. Yucca Mountain Socioeconomic Project: An Interim Report on the State of Nevada Socioeconomic Studies. NWPO-SE-022-89. Carson City, NV: State of Nevada Agency for Nuclear Projects/Nuclear Waste Project Office.

Mushkatel, D. et al. 1990. Risk-Induced Social Impacts: The Effects of the Proposed Nuclear Waste Repository on Residents of the Las Vegas Metropolitan Area. NWPO-SE-032-90. Carson City, NV: State of Nevada Agency for Nuclear Projects/Nuclear Waste Project Office.

Neus, E. 1992. "Fernald Neighbors to Get Checks. The Cincinnati Enquirer 27 March.

Nuclear Waste Technical Review Board. 1994. Letter to Congress.

Renn, O. 1993. "Risk Communication and the Social Amplification of Risk." In Communication Risks to the Public, edited by R.E. Kasperson and P.J.M. Stallen, 287-327. Boston, MA: Kluwerr Academic Publishers.

Sharp, T. 1990. "Oak Ridge Residents Comfortable With Legacy." The Oak Ridger 25 November. 
Slovic, P., et al. 1991. "Perceived Risk, Stigma, and Potential Economic Impacts of a HighLevel Nuclear Waste Repository in Nevada." Risk Analysis 11: 683-696.

Slovic, P. et al. 1993. "Perceived Risk, Trust, and Nuclear Waste: Lessons from Yucca Mountain." In Public Reactions to Nuclear Waste: Citizen's Views of Repository Siting, edited by R.E. Dunlap, 64-86. Durham, NC; Duke University Press.

Supreme Court of The State of New Mexico. 1992. "Appeal From the District Court of Sante Fe." City of Sante Fe vs. John Komis and Lemonia Komis, No. 20, 325.

Tetreault, S. 1991. "New Firms Don't Ask About Nuke Dump." Las Vegas Review Journal 20 March.

The Dallas Morning News. 1993. "Hopes High After Pantex Announcement." 13 November.

The State. 1992. "Barnwell Prospects Brighten." 26 May.

Thurlow, R. 1993. "PETT \$\$ Made The Difference." Pahrump Valley Times 8 October.

Timms, E. 1991. "Rocky Flats Debate Moves to Texas as City Seeks the Plant." The Denver Post 11 August.

U.S. Congress, Office of Technology Assessment. 1991. Complex Cleanup: The Environmental Legacy of Nuclear Weapons Production. OTA-0-484. Washington, DC.

Willette, A. 1990. "Knowledge, faith keep DOE neighbors at ease." Cincinnati Enquirer 6 May. 